\title{
Over a pork barrel
}

\author{
The US Congress is well-known for tucking special provisions for favoured projects into budget bills. David \\ Goldston explains why 'earmarks' for research and development have risen so dramatically in recent years.
}

S ummer is appropriations season in Washington DC. Congress is beginning to write the spending bills for fiscal year 2008, with the hope of having the House of Representatives and the Senate each vote on their versions before the August recess. The process is likely to be even more politically charged than usual: the new Democratic leadership in Congress will be trying to show that the president stints on domestic priorities, while the president will aim to paint Congress as profligate.

No doubt the age-old battle over congressional 'earmarks' will figure prominently in the effort to shape public perceptions of the budget. Indeed, this January the president called on Congress to halve the number of these earmarks, which provide money for a specific project or entity to help a constituent or friend.

Interestingly, Congress itself has been feeling a little queasy about earmarks of late. Although generally it sees earmarks as a fundamental prerogative, an egregious example occasionally makes headlines and cools the ardour for 'porkbarrel spending.' (The name alone points to the nineteenth-century origins of the practice.) The most recent case was the $\$ 200$-million 'bridge to nowhere' - a project, pushed through by then-chairman of the House Transportation and Infrastructure Committee Don Young (Republican, Alaska), to link a small city and an airport in Alaska that are now connected by ferry. Congress eventually rescinded the money - but not before the span gained mythical status as a symbol of wasteful spending.

Along with other scandals, that incident led the new Congress to change the rules for earmarking as one of its first orders of business. Every earmark must now be publicly listed, along with the name of the legislator who sought it.

But 'transparency' is an odd way to limit earmarking. The whole point of earmarks is to get public credit for them - at least back home. The new rules might act as a brake on the total spending on earmarks, or on particularly embarrassing projects, but they haven't reduced the demand for pork. Members of the House have requested more than 31,000 earmarks for fiscal 2008, probably a record number.

It is safe to assume that the number of earmarks requested in research and development $(\mathrm{R} \& \mathrm{D})$ programmes has grown apace. The American Association for the Advancement of

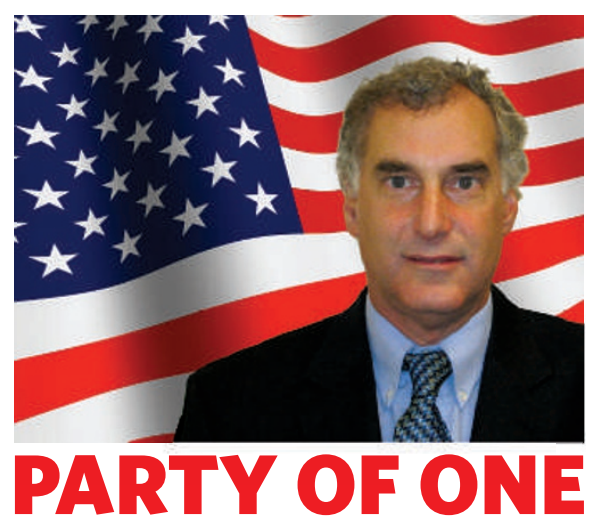

Science estimates that $\mathrm{R} \& \mathrm{D}$ earmarks grew from about $\$ 1.5$ billion in fiscal 2002 to about $\$ 2.4$ billion in fiscal 2006. (Most of the earmarks were for colleges and universities.) That's not a huge number in an R\&D budget of more than $\$ 140$ billion, but it can put a noticeable dent in funding for specific agencies, such as the National Oceanic and Atmospheric Administration, and programmes, such as the Department of Energy's hydrogen effort. Moreover, the rate of growth is a legitimate cause for concern.

Why has 'academic pork' grown so rapidly? The most obvious reason is also the most often overlooked: more colleges and universities want it. Earmark requests almost always originate with the beneficiary, not with the representatives. As schools and faculty members have become more entrepreneurial, and as federal funding has come to be seen as a test of prestige, more schools have sought money - often to do the kinds of projects the government isn't otherwise funding or for programmes that aren't strong enough to win awards in traditional grant competitions. And once one school wins some federal cash from Congress, more want to play.

And there are ever more people in Washington DC who want to help them win. Lobbying is a growth industry, generally offering high salaries. It seems that no retiring congressman goes back home anymore; they all stay in Washington and lobby - looking for clients, including research institutions, and encouraging them to seek federal funds. This structural change - a burgeoning 'private sector' that needs ever more lobbying clients to thrive makes it hard to foresee any significant reversal in earmarking trends.

Finally, Congress has bought into the notion that $\mathrm{R} \& \mathrm{D}$ is the key to economic competitiveness. So helping colleges and universities get some federal money is more enticing than it was when institutions of higher education seemed to have little relevance to larger political concerns. And economic development has always been a justification for pork-barrel projects.

With all the factors pushing towards growth in academic pork, the real surprise is that there isn't even more of it. Fortunately, academic pork is still viewed as somewhat suspect, especially among the congressmen who most closely follow science issues. Pork is seen as a way to salve the injustices and inadequacies in the standard grant-making process, not as a sign that the overall system is in need of surgery. Notably, what are arguably the two most prestigious R\&D agencies, the National Science Foundation (NSF) and the National Institutes of Health, have never been earmarked - perhaps both an effect and cause of their prestige. (Congress does sometimes push specific large construction projects at the NSF, but those are first proposed by the agency, not Congress, and Congress does not choose where to locate them.)

That doesn't mean that there hasn't been pressure to earmark the two agencies, especially from those who see peer review as a clubby system that benefits only the 'haves'. In a happy coincidence, some of the 'have nots', often schools from the south and Rocky Mountain west, are represented by conservatives who see any form of earmarking as a kind of budgetary incontinence.

Also, Congress has tried to divert some of the earmarking pressure by setting aside competitive funds for institutions in states that do not get a large share of federal R\&D funds. The programme began at the NSF decades ago, and Congress has gradually replicated it in other agencies.

So for now, academic earmarks will probably continue to grow, but not without limit. Congress is likely to remain nervous through this political cycle that too much pork will smear it with a reputation for fiscal irresponsibility. And when it comes to academic grant making, Congress still tends to believe, to paraphrase Winston Churchill, that peer review is the worst system except for all the others.

David Goldston is a visiting lecturer at Princeton University's Woodrow Wilson School of Public and International Affairs. 